\title{
Árva Márton
}

\section{Perspektívaváltások. A filmfenomenológia és a dekoloniális gondolkodás lehetséges párbeszédéról}

\begin{abstract}
Absztrakt
A tanulmány két eltérô elméleti iskola vizsgálódásai közötti párbeszéd lehetôségére világít rá, egy olyan értelmezési keret kontúrjait felvázolva, melynek segítségével jelentésteli kapcsolatok állapíthatók meg a filmek percepciós élménye és kulturális-geopolitikai specifikumai között. A modern racionalitás testetlen univerzalizmusát más-más irányokból kritizáló filmfenomenológia és dekoloniális gondolkodás fôbb állításainak bemutatása után a dolgozat a Walter Mignolo által kidolgozott „border thinking” eljárásának filmekkel kapcsolatos vizsgálatokba történô adaptálása mellett érvel. Végül néhány példán keresztül utal rá, hogy ez a módszer leginkább az ismeretelméleti pluralitás, tehát a modernitás és a kolonialitás közötti határvonal filmes kifejezôdésének elemzésére lehet alkalmas.
\end{abstract}

\section{Szerzô}

Árva Márton az ELTE BTK Film-, Média- és Kultúraelméleti Doktori Programjának doktorjelöltje, a Prizma spanyol és latin-amerikai filmekkel foglalkozó rovatának alapítója. Fóbb érdeklôdési területei a spanyol és latin-amerikai film, a posztkoloniális kulturális kapcsolatok, illetve a dekoloniális gondolkodás. Filmes tárgyú írásait többek között a francia Cinémas d’Amérique latineban, a mexikói Revista Montajesben, a Metropolisban, a Filmvilágban és a Prizmában publikálta. Szerkesztett kötete, a Kino Latino - Latin-amerikai filmrendezöportrék 2020-ban jelent meg a Prizma kiadásában.

https://doi.org/10.31176/apertura.2021.16.2.10 


\section{Árva Márton}

\section{Perspektívaváltások. A filmfenomenológia és a dekoloniális gondolkodás lehetséges párbeszédéról}

Jelen dolgozat arra vállalkozik, hogy a filmfenomenológia és a dekoloniális gondolkodás metszéspontjából kiindulva felvázoljon egy olyan értelmezési keretet, melynek segítségével kapcsolatok állapíthatók meg a filmek percepciós élménye és kulturális-geopolitikai meghatározottságai között. A felvetés aktualitását az adja, hogy noha a nyugati akadémiai diskurzusban az ezredforduló környékén kibontakozó „testi fordulat” a filmelméletben is éreztette a hatását, az ebbő́l következố belátások legfeljebb részben ${ }^{[1]}$ vezettek el oda, hogy a filmes kommunikáció testet öltöttségét hangsúlyozó teoretikus vizsgálódások nem nyugati nézốpontokat is igyekeztek számításba venni. Ezért ebben a szövegben bemutatom azokat az elméleti megállapításokat, melyek alapján a filmelméletben a testi hatásokon túl magukkal a testekkel (azok eltéréseivel, helyhez kötöttségével, történeti alá-fölérendeltségeivel stb.) is érdemes foglalkozni. Ezt követôen röviden kitérek arra, hogy milyen hozadékai lehetnek ennek a múértelmezésben.

A filmelméleti „testi fordulat” egyik legjelentôsebb irányzatának számító fenomenológia és „a kritikai elmélet sajátos fajtájának" [2] (Mignolo 2007b: 155) aposztrofált dekoloniális gondolkodás vizsgálódási terepei ugyan egymástól távol esnek, célkitûzéseik azonban kulcsfontosságú pontokon kapcsolódnak össze. A leglényegesebb ezek közül, hogy mindkét megközelítés az ismeretszerzés elsődlegesen testi mivoltát hangsúlyozva kritizálja a modern racionalitás (testetlen) univerzalizmusát, illetve az ebből következô modern/koloniális ismeretelméleti hierarchiákat. A filmfenomenológiában és a dekoloniális gondolkodásban is megtaláljuk a karteziánus dualizmus alapvetố kritikáját, tehát az elme és a test, illetve az elme és a természet elválasztásának megkérdôjelezését. Ebból következôen kezdik ki ezek az elméletek azt az instrumentális racionalitást, amely az érzékelést, az ismeretszerzést, a tudást és a kommunikációt nem helyhez és testhez kötött folyamatokként, hanem a testtôl független adottságokként, „tiszta gondolatok” és univerzálisan leírható, absztrakt igazságok alapján képzelik el. Vagyis mindkét terület szerzôi a huszadik század végéig javarészt figyelmen kívül hagyott testeket vizsgálják mint a tudás és az ismeret alternatív forrásait, ily módon megkérdôjelezve a világhoz való ismeretelméleti viszonyulás modern eurocentrikus elveit. Márpedig ha az érzékelés és kifejezés struktúráit a modern racionalitás istenszerú, testetlen perspektívája helyett a testet öltött tudatból kiindulva gondoljuk újra, akkor egyrészt adódik a testek (geopolitikai pozíció, nem, gender, kinézet, fogyatékosság stb. alapján meghatározott) eltéréseinek problémája, másrészt pedig - a filmélmény vonatkozásában - a szenzoriális észlelés és az absztrakt reflexiók viszonyának kérdése. A 
továbbiakban ezeket a teoretikus megfontolásokat fejtem ki: először felvázolom a

filmfenomenológia, illetve a dekoloniális gondolkodás ismeretelméleti megállapításait, majd a két iskola átfedéseiból kiindulva rámutatok a kettô közötti produktív párbeszéd lehetôségére.

\section{„Észlelek, tehát testet öltött vagyok” ${ }^{[3]}$ - A filmelméleti „testi fordulat” és a fenomenológia}

A filmelmélet „testi fordulata” összetett és különböző teoretikus irányokat magába foglaló folyamat, melynek közös nevezôje az 1970-es és 90-es évek között domináns, a szemiotikán, a pszichoanalízisen, illetve a marxista alapokon nyugvó filmelmélet elutasítása. A nézô testet öltöttségéból kiinduló filmelméletek szerint a narratív struktúrákkal és a filmi „tekintet” pszichoanalitikus konstrukciójával foglalkozó elképzelések túlságosan is általánosító és hiányos képet adnak a filmélményrôl, és különösen akkor vallanak kudarcot, amikor a befogadóra gyakorolt zsigeri vagy érzelmi hatást igyekeznek magyarázni.

Az ezredforduló „testi fordulatának” elméletírói szerint ezek a hiányosságok javarészt azoknak a nyugati filozófiai hagyományoknak a korlátaiból erednek, amelyekre a modern filmelméletek támaszkodnak; többek között ide tartozik az érzelmek általános megvetése. A nyugati gondolkodásban az érzelmeket hagyományosan az értelemmel ellentétesnek, a patriarchális tudományos diskurzusba való bekerüléshez „túlságosan nôiiesnek” szokás tartani, tehát olyasvalaminek, ami a magánélet vagy a szubjektivitás birodalmába tartozik, így egyszerúen nem alkalmas arra, hogy vizsgálat tárgyává váljon (Plantinga 2009: 4-5.). Ráadásul a nyugati filozófiában megfigyelhetô egyfajta bizalmatlanság a képekkel szemben, vagyis az az elképzelés, hogy a képek hazug, csábító erôvel rendelkeznek. A pszichoanalitikus filmelmélet vagy a filmszemiotika elméletalkotói a mozgóképeket egy manipulatív apparátus termékeiként közelítik meg, és a zsigeri filmélményekre gyakran rideg távolságtartással tekintenek (Sobchack 1992: 262-269.; Shaviro 1993: 14-17.). Ezen kívül fontos megemlíteni a nyugati filozófia és múvészettörténet által kialakított érzékszervi hierarchiákat is. A nyugati hagyomány ugyanis merev rangsort tart fenn az úgynevezett távolsági érzékszervek (látás, hallás) és a proximális érzékszervek (tapintás, ízlelés, szaglás) között, ez utóbbiakat „hedonisztikusnak” és alacsonyabb rendúnek tekintve (Marks 2008). Ezt a hierarchiát a modern filmelméletek is újratermelik, elhanyagolva a képek (és kisebb mértékben a hangok) melletti további érzékszervi aspektusokat a filmélmény vizsgálatában. Ez az elméleti hiányosság annál is inkább problematikus, mivel az idegtudományok bôven szállítottak empirikus bizonyitékokat arra nézve, hogy a filmnézés mindig multiszenzoros, és olyan komplexen integrált észlelési folyamatként értelmezhetô, amely nemcsak magában foglalja, hanem túl is lép a fent említett öt érzékszerv hatókörén - vagyis például a hőre, a térbeli tájékozódásra és egyéb szempontokra vonatkozó érzékelésünket is mozgósítja (Antunes 2016: 30-45.).

Az ezredforduló óta a néző testet öltöttségéből kiinduló filmelméletek ezeket a hiányosságokat 
igyekeznek korrigálni: elutasítják a „testetlen szemet” mint az elméletalkotás hivatkozási pontját, és ezzel szemben hangsúlyozzák mind az észlelt film, mind pedig az észlelô materialitását. Ezek az elméletek kifejezetten a filmélmény érzékszervi rétegeit elemzik, azokra a megközelítésekre emlékeztetve, melyeket korábban, „a 70-es évek elején a »rigorózusabb« és »objektívebb« leírási módok megjelenésével kiutasítottak a filmtudomány területérôl” (Sobchack 2004: 58). Kritizálják a modern filmelméletek középpontjában álló optikai modellt, amely a reneszánsz perspektívát adaptálja, és abból indul ki, hogy a nézố a moziban a narcisztikus azonosulási folyamatban távolságtartó megfigyelôvé vagy voyeurré válik (Shaviro 1993: 44-45.). A „testi fordulat” filmelméletei ezen kívül elutasítják a „transzcendentális determinizmus” gondolatát is, mely szerint a nézốk egyéni tapasztalatára zökkenômentesen telepszik rá a rosszindulatú apparátus által sulykolt, tisztességtelen ideológiai vagy pszichológiai üzenet (Sobchack 1992: 17-18.). Tehát passzív és védtelen megfigyelés helyett párbeszédjellegú, materiális értelemben is szituált találkozásélményként tekintenek a filmnézés tapasztalatára. A 90-es évek elején publikált úttörô jelentôségú tanulmányok ${ }^{[4]}$ nyomdokain haladva az ide sorolható szerzốk arra igyekeznek rámutatni, hogy a domináns filmtudomány az ezredfordulóig vak volt a test anatómiai és fenomenológiai felfogása közötti különbségre, amit például a német „Körper” és „Leib” szavak jelentése közötti eltérés érzékeltet. Az ausztrál teoretikus, Anne Rutherford megfogalmazásában előbbi „a boncasztalon látható statikus struktúrákra”, vagyis az élettelen testre mint „szellemmel vagy lélekkel megtöltendô tartályra” utal, addig az utóbbi az élô és megélt, „érzésekkel, érzékenységgel, észlelésekkel és érzelmekkel” teli testre vonatkozik (Rutherford 2006: 146). Rutherford amellett érvel, hogy az angol nyelvú filmtudomány anatómiai metaforái hagyományosan passziv tárgyként képzelik el a nézôi testet, ami a testi érzékelésen alapuló, megélt filmélmény és az aktív tapasztalat kérdését a háttérbe szorította, kiiktatva a testet öltöttséget figyelembe vevô esztétikai elméletalkotás lehetôségét is (Rutherford 2006: 147-149.). ${ }^{[5]}$ 
A filmfenomenológia - és különösen az a válfaja, amely Maurice Merleau-Ponty egzisztenciális fenomenológiáját adaptálja a filmnézés kontextusára ${ }^{[6]}$ - éppen azokat a hiányosságokat igyekszik kiigazítani, melyek ebbôl a filmelméleti vakfoltból következnek. Ahelyett, hogy a filmnézést a befogadó szubjektum és a szemlélt tárgy közötti egyirányú kapcsolatként fogalmazná meg, a filmfenomenológia eltörli ezt a dichotómiát, és egy olyan kommunikációs rendszert képzel el, melyben észlelô és észlelt kölcsönös függésben van, a filmi jelentés és érzelem pedig ebbôl a viszonyból születik a filmélményben. Ez az elmélet tehát az interszubjektivitást és a megtestesült létezést hangsúlyozza mint a film és a nézố közötti alapvetố kommunikációs kapcsolatot, vagyis Merleau-Ponty-nak arra az alapgondolatára épít, mely szerint a megélt testi tapasztalat közvetít a világ és az emberi tudat között. Vagyis ebben a felfogásban a testet öltött látó szubjektum egyúttal mindig látott szubjektum is, hiszen a megtestesülése önmagában a figyelem mások által látható jele. A testet öltött látás tehát egyidejűleg észlelés és kifejezés: kétirányú kommunikáció a testet öltött tudat (a látó szubjektum, az „én”) és a külvilág között (Sobchack 1992: 3-50.). Ezt a modellt a filmnézés kontextusába átültetve Sobchack azt írja, hogy „amikor moziban ülünk, és egy filmet érzékelhetônek, illetve jelentésesnek tapasztalunk, akkor mi (és az eloottünk pergó film) egy adott világnak vagyunk a vizuális (értsd: látó és látható - Á.M.) részei” (Sobchack 1992: 8).

Ez egyrészt azt jelenti, hogy a néző a testén keresztül tapasztalja meg a filmet, vagyis a test közvetít a tudat és a film között, biztosítva a kommunikatív eseménnyel járó jelentések és intenzitások áramlásának, illetve a képi és nyelvi információcserének a kereteit (Sobchack 2004: 58-61.). Másrészt azt is, hogy a filmnézés eseménye interszubjektív és kétirányú kommunikációként értelmezhetô. Vagyis fenomenológiai értelemben mind a nézôt, mind a filmet úgy kell felfognunk, mintha egy-egy testi tapasztalat birtokosai lennének, és testükön keresztül valósulna meg a különbözô jelentések észlelése és kifejezése is. Nyilvánvaló azonban, hogy a film teste jelentôsen eltér a befogadó testétôl: ahogy Sobchack kifejti, ebben a modellben a filmnek azért van szüksége testre, hogy érzékelje és kifejezze a világot a befogadó (és önmaga) számára. A film teste tehát „a tapasztalatot technológiai úton közvetítô tudatként nyilvánul meg számunkra” (Sobchack 1992: 168). Jennifer M. Barker ezt a gondolatot árnyalja tovább The Tactile Eye címú könyvében, és azt vizsgálja, miként képes a film a saját vizuális létezésének keretein belül jelentéseket rögzíteni és kifejezni. Persze a filmnek ez a fajta testet öltött vizuális létezése a gyakorlatban annak felel meg, ahogy technikailag megörökít vagy létrehoz egy világot, majd bemutatja azt a nézônek. Vagyis amit fenomenológiai értelemben a film testet öltött kommunikációs gesztusaiként értünk, az nem más, mint a térben való mozgás és zoomolás, a hangfelvétel, a dolgok felületének pásztázása vagy éppen a montázs ritmikus elrendezése. Ezek azok a film teste révén létrejövő kommunikációs gesztusok, amelyeket a nézô teste érzékel, és a testet öltöttségnek ez a kölcsönössége teremti meg a film és a nézô közti jelentéses kommunikáció peremfeltételeit, hiszen „a nézô és a film világban való létezésének, látásának és érzékelésének bizonyos módjai annak ellenére hasonlóak, hogy nagy különbségek vannak ember és gép között; az egyik vér és szövet, a másik fény és celluloid" (Barker 2009: 9). 
A fenomenológiai megközelítés tehát a filmnézés immerzív jellegét hangsúlyozza, vagyis azt, hogy a film „testi modalitásban”, a testet öltöttségen keresztül kerül kapcsolatba a nézôvel: a jelentések észlelése és kifejezése, a külsô világ és a belsô tudat a testben érnek össze (Sobchack 2004: 65). A filmfenomenológia szerzői szerint ez a testi, illetve érzékszervi érintkezésbôl születô filmélmény a film és a nézô közötti bensôséges, intim kapcsolat eredménye, ami leginkább élố testek találkozásához hasonló, és mint ilyen, érzelmeket és érzeteket szabadít fel, melyek megelôzik a tudatos gondolkodást (Sobchack 2004: 66-79.; Barker 2009: 13-16.). Ebből az is következik, hogy a fenomenológia szerint nézôként még azelôtt „,vonz magához egy film tapintható, zsigeri módon [keletkezó érzések miatt]”, hogy időnk lett volna az általa ábrázolt fiktív-narratív világ valamelyik szereplôjével azonosulni (Barker 2009: 16, kiemelés az eredetiben). Barker egy sor esettanulmányon keresztül ki is dolgozza a filmnézés testet öltöttségéből származó „tapintások filmes módozatainak" tipológiáját (Barker 2009: 20). Ezzel arra próbál választ adni, hogyan lehet a filmes kifejezőeszközök és az emberi test gesztusai közötti kapcsolatot megragadni akkor, ha magát a filmnézést testek érintkezéséhez, illetve tapintáshoz hasonló élményként közelítjük meg. A fenomenológia tehát a „filmtárgyat” távolról szemügyre vevô befogadó elvont képzete helyett „az anyag és a jelentés összefonódása” mellett érvel (Sobchack 2004: 100). Olyan fogalomhasználatot javasol, amely elmossa a határokat a szubjektum és a tárgy, az én és a másik vagy a filmképen „innen” és „túl” között, a pólusok elválasztása helyett képlékenyebb összekapcsolódásokban gondolkodva. Mindezt éppen azért teszi, mert a filmekkel való találkozás során a szenzórium stimulációja megelôzi és elôfeltételezi (sốt, olykor meghatározza) a tudatos gondolkodás folyamatait.

\section{„Ott vagyok, ahol gondolkodom” [7] - Dekoloniális gondolkodás}

Amennyiben a fentiek alapján elfogadjuk, hogy a filmbefogadás alapja a közös világban megragadható testet öltöttség, annyiban fontos figyelembe venni azt a történeti logikát is, amely szerint a szubjektumok testei ebben a világban elrendezésre, illetve megkülönböztetésre kerülnek. A dekoloniális gondolkodás (más néven modernitás/kolonialitás kutatási program) ebból a szempontból elemzi és kritizálja a nyugati modern filozófiai hagyományt és az erre épülô hatalmi gyakorlatokat. Ezt az elméleti iskolát fôként kortárs latin-amerikai filozófusok és szociológusok munkássága alkotja, akik szerint azok után, hogy a „három világ felosztás” érvényét vesztette, „a modernitás új értelmezésére van szükség” (Escobar 2007: 180). Alapvetố állításuk, hogy az a történelemszemlélet, amely a modernitást teljes egészében Európán belüli tényezókkel magyarázható jelenségként keretezi, hiányos és torz, mert kritikátlanul tükrözi azt az eurocentrikus perspektívát, amely az elmúlt 500 év történelmi eseményeit az európai kivételesség és felsôbbrendûség mítosza szerint meséli el (Dussel 1998). A modernitás történetét planetáris nézôpontból újraolvasva - vagyis az Európa és a világ más részei között kiépülő kapcsolatokat figyelembe véve - ugyanis az látszik, hogy „az [Európa] kizárólagos eredményeiként számon tartott értékek, felfedezések, találmányok, technológiák, politikai intézmények és egyéb 
vívmányok sora valójában következménye [nem pedig oka] annak, hogy az interregionális rendszer korábbi hatalmi központja [...] Európa felé mozdult el" (Dussel 1998: 5, kiemelés módosítva). Ezt az elmozdulást, vagyis azt, hogy az európaiak az emberi történelem elsô világrendszerének - a modernitásnak/kolonialitásnak ${ }^{[8]}$ - a középpontjába kerültek, az amerikai kontinens 1492-tôl kezdôdô erôszakos gyarmatosítása, illetve az ennek nyomán kialakított ismeretelméleti rendszer tette lehetôvé (Dussel 1998: 9-11.).

A dekoloniális kritika a nyugati-eurocentrikus uralom ismeretelméleti megalapozásának elemzésekor kulcsszerepet szán az eltérô testek, illetve testet öltött szubjektumpozíciók kérdésének. Aníbal Quijano perui szociológus nagyhatású cikkekben járta körül a kolonialitás (más fordításban „a hatalom gyarmatisága” ${ }^{[9]}$ ) koncepcióját, amely a gyarmati uralom elemzésére használható legfontosabb szempontokat sûríti magába. A kolonialitás nemcsak a föld és az erőforrások kisajátítására, a közvetlen politikai uralomra, valamint a nyelvvel, a nemiséggel, illetve a szexualitással kapcsolatos hierarchiákra vonatkozik. Quijano a gyarmati uralom fenti megnyilvánulásainak alapját a szubjektivitás feletti uralomban, tehát az elnyomottak képzeletének gyarmatosításában látja (Quijano 2000; 2007). Ennek lényege, hogy a gyarmatosítók elvetik az alávetettek világról alkotott tudását, hitét és szimbólumait, kisajátítják néhány olyan elképzelésüket, amelyet anyagi haszonszerzésre tudnak fordítani (ilyen például a bányászat és a mezôgazdaság terén használt ôslakos tudás), majd saját eszméiket erôltetik rá a gyarmatosítottakra.

Ennek az eljárásnak az egyik legfontosabb következménye a „rassz” mentális kategóriájának erôszakos meghonosítása. A „rassz” a gyarmati világrendszer társadalmának felosztását és megszervezését szolgálta azáltal, hogy az uralmi viszonyt olyan „természetes” tényezóként láttatta, amelyet a „biológiailag meghatározott” alsóbbrendûség és felsôbbrendûség magyaráz (Quijano 2007: 171). Mint Quijano kifejti, a 16. századtól kezdve ezek az elképzelések alapozták meg a kapitalista gazdaság egészén belüli munkamegosztás kereteit. Vagyis bizonyos „rasszokat” bizonyos feladatokhoz és a munka ellenôrzésének különféle formáihoz társítottak (Quijano 2000: 536-540.). A gyarmatok ôslakos lakosságának nagy részét például jobbágyságra korlátozták; míg a meszticek (spanyol férfiak és indián nôk gyermekei) szolgáltatásokat nyújthattak, például zenélhettek a fehéreknek; a feketéket pedig teljes egészében rabszolgasorban tartották. Mindezen társadalmi csoportokat a fehér európaiak irányították és ellenôrizték, és nekik arra is lehetôségük volt, hogy piacon értékesítsék az általuk megtermelt árut vagy bérmunkát vállaljanak. Így a modern/gyarmati világrendszer keretein belül a „rassz” kategóriája nemcsak új társadalmi identitások elterjedését eredményezte, hanem azt is lehetôvé tette, hogy az európai gyarmatosítók kizsákmányolják a nem fehérek munkaerejét, és fizetetlen munkájukból tôkét halmozzanak fel (Quijano 2000). A modern világkapitalizmus gazdasági struktúrája erre a modellre épült: egyrészt a felügyelete alá vonta a globális munkamegosztást, másrészt rendelkezett a „periféria” természeti erôforrásai felett. A modernitás elsố (spanyol-katolikus) szakaszában beindult termelési rendszer az európai kontinens egészénél is jóval nagyobb természeti területet, valamint mintegy 25 millió ôslakos és 14 millió afrikai rabszolga munkaerejét zsákmányolta ki. Ezt követôen a második (angolszász-protestáns) szakaszban, az ipari forradalmat követően történt meg ennek a gazdasági 
uralomnak az egész világra való kiterjesztése (Dussel 1998; Grosfoguel 2002).

Ahogy Quijano megállapítja, ezek a materiális gyakorlatok döntônek bizonyultak a modern nyugati racionalitás megteremtésében, mely definíció szerint „kizárólag európai eredetû vívmány, mégis univerzális érvényú paradigmaként határozza meg a tudáselôállítás, illetve az emberiség és a világ többi része közötti kapcsolat lehetôségeit" (Quijano 2007: 171-172.). Quijano leírása szerint az európai racionalitás alapfeltevése, hogy a tudás egy szubjektum-objektum viszonyból születik, ahol a szubjektum egy önálló, reflexióra képes elme, az objektum pedig a szubjektumtól elválasztható, megismerhetô tulajdonságokkal rendelkezô tárgy (alapesetben a természet) (Quijano 2007). Az „elme” és a „tárgy” dualizmusának descartes-i tétele a 17. század elején alakította át a nyugati középkori ismeretelméleti modellt (amely Istentôl eredezteti a tudást) a modern paradigmává (amely az embert tekinti a tudás forrásának). Ez az elmozdulás alapvetố jelentôségú volt abban a tekintetben, hogy lehetségessé tette a társadalmi mobilitás gondolatának megjelenését, vagyis felszabadította az európai egyént a merev, premodern társadalmi struktúrák alól, melyek születésüktôl fogva rögzítették az emberek társadalmi pozícióit (Quijano 2007: 173). Ugyanakkor, ahogy Ramón Grosfoguel Puerto Ricó-i szociológus érvel, ez a történelmi fordulópont sem változtatta meg a nyugati diskurzus azon retorikáját, amely a tudásra „idôtôl és tértôl független egyetemes Igazságként" tekint (Grosfoguel 2007: 214).

A tudáselóállítás ilyen módú megalapozása áll a dekoloniális kritika kereszttüzében, amely két sarkalatos pontra hívja fel a figyelmet. Egyrészt a modern racionalitás az absztrakt univerzalizmus és semlegesség mítoszai révén hatásosan elrejti azt a nagyon is konkrét és helyhez/testhez kötött nézôpontot, amelybôl kiindulva az általa termelt tudás és ismeret előállításra kerül. Másrészt ez az ismeretelméleti paradigma kizárólagosnak tünteti fel saját magát, vagyis csak a modern, racionális keretek között születô tudást fogadja el, minden más tudásrendszert kizár az érvényesség köréből, és semmilyen alternatív tudásformát nem ismer el a sajátjával egyenrangúnak (Mignolo 2007a: 451; Grosfoguel 2007: 214). Abszolút egyetemességet követel saját perspektívájának, miközben az ettôl eltérô geopolitikai nézôpontból születô alternatívákat nem racionálisnak, tehát természetüknél fogva alsóbbrendúeknek tekinti. ${ }^{[10]} \mathrm{Az}$ így születô eurocentrikus diskurzus a történelmi fejlôdés egyetlen lehetséges modelljét állítja fel, és elvárja, hogy a világ teljes lakossága kövesse azt. Ebből a perspektívából a nem nyugatiak leigázásának lokális történetei vagy láthatatlanok, vagy a haladás, illetve a fejlôdés „univerzális” eszméivel igazolhatónak tûnnek (Mignolo 2012: xvi-xviii.). Ahogy Quijano rámutat, a tudás és a szubjektivitás gyarmatosítása a mai napig a nyugati uralom leghatékonyabb módszere, és „alapvetô részévé vált a részben vagy teljesen európaizált társadalmak és kultúrák újratermelôdési feltételeinek" (Quijano 2007: 170).

Így amikor a dekoloniális gondolkodók kritizálják a modernitás hiányos, eurocentrikus szemléletú történetét, akkor egyben a modern szubjektivitás kialakulásának hátterében álló racionális tudásés ismeretelméleti paradigma megkérdôjelezésére is törekednek. Ennek módja a nyugati modern racionalitás állítólagos egyetemességének vitatása, illetve „a különbségekből kiinduló, alternatív helyi és regionális világok megengedése felé mutató gondolkodás radikális potenciáljának szabadjára engedése" (Escobar 2007: 183-184.). Az argentin dekoloniális gondolkodó, Walter D. 
Mignolo ennek a konkrét stratégiáit, vagyis „a dekolonialitás nyelvtanát” vázolja fel Delinking címú összefoglaló cikkében (Mignolo 2007a). Ebben a modern racionalitásról történô „episztemológiai leválásnak” két mozzanatát írja le, melyeket a tudás „geo-politikájának” és a tudás „testbe íródásának" nevez (Mignolo 2007a: 462-484.). Ez az ismeretek forrásainak konkrét földrajzi és testet öltött társadalmi pozíciói iránti elkötelezett figyelmet jelenti, tehát annak a mítosznak az elutasítását, hogy az ismeret egy külsô és semleges nézôpontból ered (legyen az Isten vagy a nyugati racionális elme). Vagyis szerinte a testet öltöttség komolyan vételével kell számot adni a különféle ismeretelméleti perspektívák partikularitásairól, és fel kell oldani a modern racionalitás retorikája által termelt ismeretelméleti hierarchiákat. Mignolo cikke érzékletesen fogalmazza meg, miként ássa alá ez a dekoloniális felfogás a modern karteziánus logikát:

Hogyan késztet gondolkodásra például Hanna Arendt, Jacques Derrida vagy Frantz Fanon? Nem egyszerúen az történik, hogy a lebegó szellem vagy az absztrakt kategóriák az égből az elmémbe szállnak, gondolkodni kezdek, és ettôl rájövök, hogy vagyok. Éppen fordítva: érzem a földrajzi, történeti és biográfiai helyzetemben történt megtestesülésemet, és ebből a testet öltöttségból jövök rá a létezésemre, méghozzá arra, hogy egy olyan modern/gyarmati világban vagyok, amely a bolygó lakosságát a rassz, a szexualitás és a gender kategóriái alapján osztotta fel, és így kezdek gondolkodni. (Mignolo 2007b: 505)

A dekoloniális gondolkodás tehát a modern racionalitás redukcionizmusa helyett egy olyan globális kritikai öntudat mellett áll ki, amely nem arra törekszik, hogy az eltérô helyzetekben és más-más testekben megélt élmények különbségeit absztrakt univerzálékká szintetizálja (Mignolo 2007a: 500). Ez a megközelítés szakít azzal az évszázados gyakorlattal, mely a bolygón élő emberek többségének élményeit nem ismerő, könnyen körülhatárolható társadalmi csoport (fehér, európai, keresztény férfiak) testet öltött pozíciójából megalkotott ismeretelméleti modellt kritikátlanul fogad el általánosan és egyedül érvényes perspektívaként. Mignolo „episztemológiai leválása” azt teszi lehetôvé, hogy a modern racionális gondolkodási rendszer mellett más földrajzi helyhez és testet öltött tapasztalatokhoz kötôdő (tehát nem nyugati, nem fehér, illetve nem férfiak által elôállított) tudás is egyenrangúként jelenhessen meg. Így a korábban egyfajta (semlegesnek láttatott, de valójában eurocentrikus) nézôpontból elbeszélt történeti diskurzusok mellett újra helyet kaphatnak ettôl eltérô perspektívájú leírások is.

\section{A "border thinking" beépítésének lehetôségei a filmek vizsgálatába}

Mint láttuk, mind a filmfenomenológia, mind a dekoloniális gondolkodás a testet öltött ismeretszerzésből kiindulva vonja kétségbe a modern nyugati ismeretelméleti hagyomány „testetlen” tételeit. Noha eltérô okokból és más-más gondolati tradíciókra hivatkozva teszik ezt, megállapításaik mégis egyként sürgetik olyan módszertani keretek kialakítását, amely a világ, illetve a kommunikatív aktusok észlelését nem rendelik alá a modern/gyarmati elveknek és 
hatalmi hierarchiáknak - legyen szó a testetlen gondolat képzetérôl, a távolsági érzékszervek preferenciájáról vagy éppen egyetlen fajta geopolitikai perspektíva univerzálissá nyilvánításáról. A dolgozat hátralevô részében ezért amellett fogok érvelni, hogy a két iskola produktív párbeszédbe hozható, vagyis a dekoloniális szempontok és módszerek alkalmazása a filmelmélet, illetve a filmek tanulmányozásának területén is indokolt. Ennek érdekében röviden bemutatom, miért lehetséges és miért hasznos a modernitás/kolonialitás kutatási program keretében kidolgozott „border thinking” („határgondolkodás”) koncepciója a filmnézés testet öltött tapasztalatának vizsgálatában.

Ugyan a posztkoloniális kritikán belül jelentôs munkák születtek, melyek nagy gondot fordítanak a film- és médiaszövegek elemzésére, ezek javarészt a nem nyugati kultúrák reprezentációját, a domináns mozgóképkultúrában elterjedt rasszista sztereotípiák kérdését, illetve ezekhez hasonló, a diskurzusban megjelenô motívumokat helyezik elôtérbe. Tehát elméleti keretrendszerük elsôsorban a szövegek, szimbólumok és narratívák szintjére fókuszál, és kisebb hangsúlyt fektet a múvek szenzoriális kifejezési stratégiáira, illetve percepciós élményére. Ella Shohat és Robert Stam például klasszikusnak számító, Unthinking Eurocentrism címú könyvükben azt elemzik, hogy a film és az audiovizuális média miként ágyazódott a gyarmati és birodalmi elnyomás gépezetébe, illetve milyen mozgóképek kísérelték meg, hogy ennek az eurocentrikus diskurzusnak „visszabeszéljenek”. Megfogalmazásuk szerint a domináns média monologikus, vagyis egynézốpontú leírásainak igazán hatásos alternatívája az a fajta pluralitás lehet, amely „diskurzusok összjátékában”, hangok polifóniájában”, illetve a „multivokalitásban” ragadható meg (Shohat és Stam 2014: 215).

Az egzisztenciális fenomenológia és a dekoloniális gondolkodás párbeszédéból születô elméleti keret éppen ezeket a többszólamú mozgóképes megszólalásmódokat, illetve összjátékokat teheti megragadhatóvá és árnyaltabban elemezhetôvé. Mint láttuk, mindkét elméleti iskola az ismeretszerzés interszubjektív mozzanatként történô meghatározása révén igyekszik feloldani a modern racionalitás „monologikus leírásait”. Erre a Vivian Sobchack által leírt egzisztenciális filmfenomenológia keretein belül azért van lehetôség, mert az Merleau-Ponty-nak azon az elméletén alapul, amely az én-tudat kialakulását interszubjektív tényezóknek rendeli alá, szemben a pszichoanalitikus filmelméletet megalapozó lacani felfogással, amely az én tárgyiasítását és a tükörstádiumon keresztül történő megkettôződését hangsúlyozza (Sobchack 1992: 100-143.). Merleau-Ponty modellje - a dekoloniális kritika felfogásához hasonlóan - abból indul ki, hogy a megélt és észlelt test felel a szubjektivitásért, és az én-tudat kialakulásának folyamata során „a létezés kölcsönösségére” ismerünk rá (Sobchack 1992: 127). Eszerint a szubjektum a testet öltöttség tapasztalatából alakul ki, amit egy olyan világban észlel, amelyen más testekkel osztozik. Így a tudat megképződésekor mind az „én”, mind pedig a „másik” egyszerre kap szubjektum- és objektumstátuszt: felismerem, hogy az én testem is úgy látható mások számára, ahogy én látom mások testét (Sobchack 1992: 119-128.). A testet öltött látás tehát Merleau-Ponty és Sobchack számára is interszubjektív természetû egzisztenciális esemény, ami azt jelenti, hogy a látás (és tágabb értelemben az észlelés) aktusa a kölcsönösségen alapul, nem pedig a másik tárgyiasításán és 
a felette történő (vizuális) uralmon. „A látás mint a testet öltött észlelés egyik formája így nemcsak a látott és látható világhoz biztosít alapvetố hozzáférést, hanem saját magunkhoz is - egyszerre vagyunk mások által látott látható szubjektumok, illetve másokat nézô látó szubjektumok" (Sobchack 1992: 98). Ezek az elvek összecsengenek Quijano érvelésével, mely szerint:

Minden egyes individuális diskurzus vagy reflexió interszubjektív struktúrákból ered. Ezeken belül és ezekkel kölcsönhatásban tud létrejönni. Innen nézve tehát a tudás nem egy elszigetelt szubjektum és valami egyéb viszonya, hanem több szubjektum interszubjektív viszonya valamilyen cél érdekében. (Quijano 2007: 173)

Ráadásul Sobchack arra is utal, hogy filmelmélete nyitott olyan irányokba is, mint amilyenek a tudás „geo-politikájának” és a tudás „testbe-íródásának” dekoloniális eljárásai. A szerzô leszögezi, hogy „különböző kulturális és történeti gyakorlatok rendszerint élnek a megélt testtel kapcsolatos általánosításokkal és megkülönböztetésekkel” (Sobchack 1992: 145). Az ilyen diskurzusok közül pedig nemcsak azokat ismeri fel, amelyek a „nem” és a „rassz” testi kategórián alapulnak, hanem azokat is, amelyek „idôs”, „túlsúlyos” vagy „fogyatékos” testeket írnak le (Sobchack 1992; 2004). Sobchack szerint a filmfenomenológia a testet öltöttségből következô egzisztenciális kommunikatív funkciókkal foglalkozik, vagyis a test-fogalom, amivel dolgozik, nem univerzális és esszencializált, hanem potenciálisan sokféle. Tehát az egzisztenciális fenomenológia modellje a modernitás/kolonialitás-elválasztás eltérô oldalain helyet foglaló testet öltött szubjektumok élményeit és elbeszéléseit is képes teoretikusan értelmezni. ${ }^{[11]}$

Ugyanakkor Sobchack azt is jelzi, hogy további vizsgálatokra van szükség, amelyek a testek olyan sajátos, kulturálisan konstruált „pozícióival” foglalkoznak, amelyekhez különféle észlelések és perceptuális tapasztalatok társulhatnak (Sobchack 1992: 143-147.). A „border thinking” stratégiája éppen arra nyújt lehetôséget, hogy a modernitás/kolonialitás világrendszerének kontextusán belül létrejött - testi és geopolitikai kategóriák alapján osztályozott - ismeretelméleti pozíciók, illetve perspektívák sokféleségét (f)elismerje. A fogalmat Mignolo a modern racionalitás alternatívájaként vezeti be a dekoloniális gondolkodás repertoárjába, és a „tudáselóállítás kritikai reflexiójának” (Mignolo 2012: 11) módszereként definiálja, ami a modern/gyarmati világrendszer határairól kritizálja a nyugati modernitás ismeretelméleti rendszerét (Mignolo 2007a: 497). Mignolo elismeri, hogy a modern/gyarmati paradigma „történetileg megkerülhetetlen referenciaponttá” (Mignolo 2012: xxv) vált a bolygó 500 éven át tartó kolonialitása során, ezért az eurocentrikus diskurzus totalitásra törekvố retorikáját megkérdôjelezô gondolkodók hiába is próbálnának olyan perspektíva után kutatni, amely teljesen kívül esik annak hatókörén, és ahonnan kiindulva az elnyomottak ismeretelméleti szabadsága maradéktalanul helyreállítható. Ezért képzeli el a tudásformák demokratikus-dekoloniális egymás mellett létezését a modernitás és a kolonialitás határán: ott, ahol a nyugati modern racionalitás más világértelmezési módokkal áll kapcsolatban, és ahonnan nézve megmutatkozik, hogy „abszolút tudása” valójában töredékes és részleges, mert korántsem minden testet öltött szubjektum élményeit képes magyarázni. A határvonalról nézve többfajta gondolati opció is érvényesnek látszik, és a modern racionalitás csak egy a lehetséges 
tudásformák között. A modernitás és a kolonialitás határán történő gondolkodás tehát egyfajta megkettôzött perspektívát feltételez, amely nem tartozik egyértelmúen a gyarmatosító és a gyarmatosított episztemológiai vonzáskörzetébe sem, vagyis semelyik életmód, kulturális hagyomány, illetve világértelmezési modell sem határozza meg kizárólagosan (Mignolo 2012: 18-53.). A „border thinking” lényege tehát, hogy többféle ismeretelméleti rendszer létét ismeri el anélkül, hogy hierarchiába rendezné óket. Vagyis a „border thinking” keretei között a modern/gyarmati „absztrakt univerzálék” elveszítik a privilégiumaikat, és „lehetségessé válik a tudás (a modernitás perspektívájából nézve) egymással összeegyeztethetetlen formái között történô érintkezés. [...] Ez a border thinking kulcsmozzanata: dichotóm fogalmakból kiindulva gondolkodni, ahelyett, hogy a világot dichotómiákba rendeznénk" (Mignolo 2012: 85, kiemelés az eredetiben).

A „border thinking” eljárása tehát alaposabb megértést enged meg olyan múvek filmes kifejezésmódjának elemzésében, melyek valamilyen módon a modernitás/kolonialitás megnyilvánulásaival foglalkoznak, illetve melyek retorikájában szerepet kapnak nem modern gondolati kategóriák, illetve a modern normákhoz nem illeszkedô szubjektumok élményei is. Ilyen esetekben a „border thinking” stratégiája termékeny módon segíthet elkerülni, hogy a nyugati ismeretelméleti hagyomány határain túlra mutató mozgóképes munkákat is a nyugati értelmezô modellek kizárólagos ellenőrzése alá vonjunk. Ha ugyanis a „border thinking” eljárását a filmfenomenológia terminusain keresztül a testet öltött filmélmény szerkezetére vonatkoztatjuk, akkor az elemzés figyelmet tud fordítani a filmélmény reprezentatív/diszkurzív rétege mellett a hagyományosan „elnyomott”, testet öltött/szenzoriális kifejezésrétegekre is, és ezek adott esetben izgalmas dialógusba is rendezôdhetnek. A két elméleti iskola közötti analógia így látványosan kirajzol egy olyan filmelemzési módszert, mely során ugyan nem kell teljesen lemondanunk az eurocentrikus akadémiai hagyományba illeszkedô, szemiotikai, pszichoanalitikus vagy éppen marxista ihletésú diskurzusanalízisekrôl, de rá tudunk mutatni ezek szükségszerú töredékességére, és a vizsgálatot ki tudjuk egészíteni olyan elemzésekkel is, amelyek a filmélmény testet öltött rétegével is érdemben foglalkoznak.

Vivian Sobchack szerint „legelôször mindig a testet öltött létezés nyelve vesz minket körül”, és csak ezt követôen artikuláljuk a tapasztalatunkat szövegek és szimbólumok formájában (Sobchack 1992: 12). Tehát a materiális világban való testet öltött létezésünk egy olyan alapvetô kommunikációs rendszert alkot, melyben a megélt testünk önmagában jelentéses, észlelésre és kifejezésre képes. Vagyis már jóval azelôtt egyfajta kölcsönös párbeszéd részei vagyunk a világgal és a többi testet öltött szubjektummal, hogy „tudatosan úgy döntenénk, hogy a világból felénk érkező jelentést absztrakt és körülhatárolt egységekké formálnánk" a nyelv és a gondolkodás által (Sobchack 1992: 12). Ez azt is jelenti, hogy a testet öltöttség a filmélményben nem egyszerúen a diszkurzív vagy szimbolikus jelentések hordozója, hanem sokkal tágabb értelemben is megalapozza a tapasztalat szemiotikáját. A filmek nem kizárólag a nyelvileg artikulálható kódok szintjén képesek megszólítani az érzékeinket, hanem ennél jóval közvetlenebbül, szenzoriális és affektív módon is kommunikálhatnak. Ha a filmészlelésünk természetes állapotában is a 
valóságérzékeléshez hasonló módon multiszenzoros (Antunes 2016: 3), akkor a filmélmény jóval sokrétúbb lehet a történetmesélés, a dekódolható üzenetek, szimbólumok és vizuális metaforák megértésénél, és további jelentéses észleléseket, illetve érzeteket is közvetíthet. Vagyis a filmes észlelés és kifejezés struktúrája - még a kommersz játékfilmek területén is, nem is beszélve a kísérletibb munkákról - rengeteg olyan megoldással élhet, melyek a nézô testi megszólítása révén a narratív kauzalitás domináns „egységesítô elvének” (Bordwell 1985: 157) alternatíváját nyújtják.

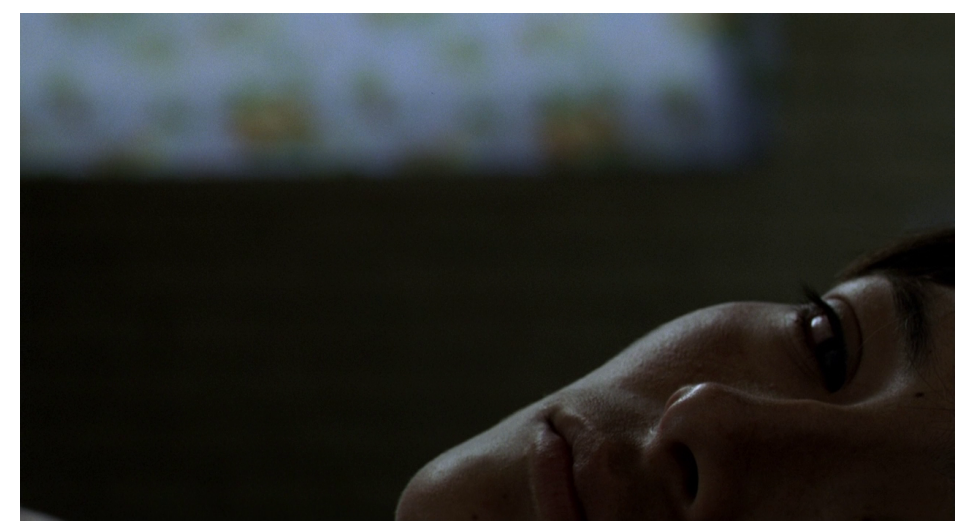

Fausta éneke (La teta asustada. Claudia Llosa, 2009)

A testet öltöttséget és az ismeretelméleti pluralitást is figyelembe vevô módszer látványosan tudja árnyalni a filmértelmezést, ha például olyan kortárs munkákat vizsgálunk, melyek túlmutatnak a nyugati kultúra keretein. Randal Halle amellett érvel, hogy a 90-es évek óta a filmfinanszírozás és forgalmazás különösen gyors ütemben transznacionalizálódott, a múvészfilmek értelmezésére használt elméleti keretek viszont csak sokkal lassabban alakulnak át. Ezáltal a közönség továbbra is a huszadik század második felében (a maitól radikálisan eltérô, erôs állami infrastruktúrájú filmkultúra kontextusában) kialakult fogalmakkal közelíti meg a 21. század nemzetközi piacára szánt audiovizuális termékeket (Halle 2010: 304). Így ma számos film fejti ki hatását a lokális kulturális hagyományok és kifejezésmódok, illetve a transznacionális filmkultúra intézményi struktúrái és nyilvánossága által egyaránt meghatározott térben. Jó példa erre a Fausta éneke (La teta asustada. Claudia Llosa, 2009), amely spanyol-perui koprodukcióban készült, svájci és német filmalapok támogatásával az egyik legnevesebb európai nemzetközi filmfesztivál, a Berlinale fốdiját kapta meg 2009-ben, ugyanakkor fôszereplôje és kiinduló konfliktusa az andoki kecsua kultúrához kötődik. A Fausta éneke a Fényes ösvény gerillaszervezet és a perui katonaság véres küzdelmei által terrorizált andoki területekrôl Lima külvárosába menekült család egyik fiatal tagját, Faustát követi. A lány a kecsua indián kultúra és a modernizált nagyváros ismeretelméleti kettôsségében találja magát, ráadásul egy jómódú fehér zongoramúvész házába kell szegôdnie háztartási alkalmazottként, hogy pénzt gyújtsön anyja temetésére. A múértelmezéshez az emlékezeti diskurzusok és a vizuális szimbólumok felól közelítô Paul A. Schroeder-Rodríguez a perui múlthoz való kétfajta hozzáállás közötti konfliktust látja a film központi kérdésének, és elemzésében többek között a visszaemlékezés-jelenetek vizuális kompozícióit hasonlítja össze (Schroeder-Rodríguez 2016: 284-285.). Szerinte az a jelenet, melyben Fausta munkaadója oszt meg egy gyerekkori emléket, és az egyes szereplôk alakja egymástól vizuálisan elkülönül, 
ellentétbe helyezhetô azzal a szekvenciával, melyben indián nôk kollektív módon emlékeznek meg az ôket ért megpróbáltatásokról, és alakjuk „rizómaszerúen” egymásba fonódik (SchroederRodríguez 2016: 286).

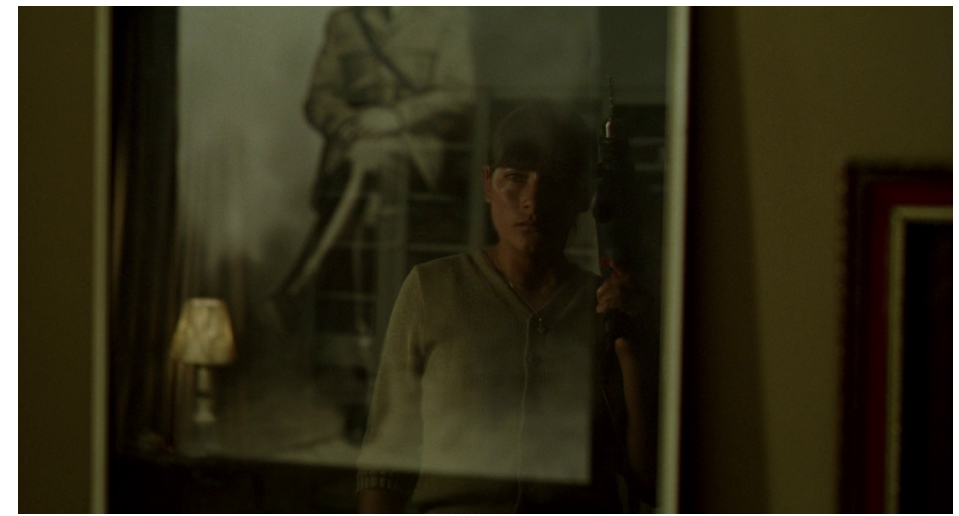

Fausta éneke (La teta asustada. Claudia Llosa, 2009)

Ez az elemzés értékes megállapításokat tesz, ugyanakkor keveset árul el a Fausta éneke komplex filmes kifejezésmódjáról, nézôi élményérôl és a Claudia Llosa életmúvét sûrûn átszövô intézményi és kulturális kettôsségrôl, melyek gyakran vetik fel a szerzôvel kapcsolatban a neokoloniális tekintet problémáját. ${ }^{[12]}$ Ezeknek az árnyalatoknak a megértéséhez érdemes a film szenzoriális retorikáját, illetve a dekoloniális értelemben vett „határpozícióját” is figyelembe venni. Ha például megfigyeljük azt a jelenetet, melyben Fausta először találkozik munkaadójával, feltúnik kép és hang dialógusa, vagyis a hatékony információgyújtésre használt vizualitás, illetve a nézô testet öltöttségét „a filmes textúrákba beleburkoló” hangi kifejezôeszközök kettôssége (Elsaesser és Hagener 2009: 131-137.). A narratív szempontból kevéssé beszédes képeken a barokkosan fényúzô nagypolgári lakásbelsôrốl és az ebben a közegben egzotikus látványosságként feltûnô indián lányról készült statikus beállítások dominálnak. Történetet inkább a hangsáv mesél, mégpedig Fausta szemszögébôl. Képen kívülrôl halljuk a munkaadó szobájából érkezô zongorázást, csörömpölést, a Faustát hívó csengôt, majd a fúrás kiszúrôdô zaját is. Fausta tehát mindenekelôtt látvány a jelenetben: kívülrôl látjuk ôt, és amit ô vizuálisan érzékel, az javarészt - egy kis mélységélességú társított beállítást leszámítva - rejtve marad elôttünk. A hangsávban ugyanakkor nagyon is értesülünk Fausta élményeiról, sôt, intim közelségból követjük ốt: befogadóként mi is a hangsávban beállt változásra leszünk figyelmesek, majd vele együtt közeledünk a munkáltató zajaihoz. 


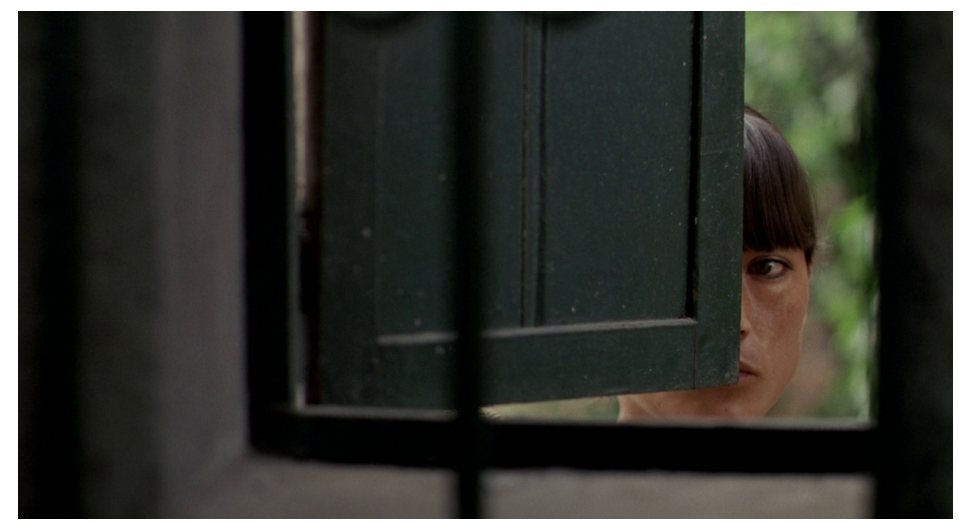

Fausta éneke (La teta asustada. Claudia Llosa, 2009)

A fenti rövid jelenetleírás elvezet annak felismeréséhez, hogy a látás távolsági érzékszerve és a hallás a test belsejéhez és rezgéseihez közvetlenebbül kapcsolódó érzetei a film egészében következetesen rendeződnek a fôvárosi és a kecsua kultúrközeghez, illetve a modernitás és a kolonialitás pólusaihoz. Míg Fausta a vizuális síkon rendre kiszolgáltatottként, eurocentrikus indiánábrázolásokhoz igazodó módon gyerekes, istápolásra szoruló figuraként jelenik meg, addig a hangsáv az ô érzékenységét hozza közel a nézôhöz, a történetet a félénk lány perspektívájából is megvilágítva. A színpadiasan elrendezett képkompozíciók és a lassú kameramozgások a testet öltött nézôt érzékszervi bevonódás helyett távolságtartásra, az ábrázolt kulturális miliô „belakása” helyett egy külsô megfigyelô attitúdjének felvételére ösztönzik. Fausta számára ráadásul a vizualitás mint ismeretszerzési forrás rendre félrevezetônek bizonyul: a fôhősnô visszatérôen félreérti a látható jeleket, mint amikor a földbe ásott gödör láttán megretten, hogy unokabátyja eltemette anyja holttestét, pedig csak medencét ásott, ahol a gyerekek játszhatnak. Ezzel szemben a hangok anélkül hozzák közelebb a befogadóhoz Fausta érzéseit és észleléseit, hogy ezt bármilyen képi jel felerôsítené. Amikor például a fôhốs kinyitja a munkáltatója kertjét a szomszédos piactól elválasztó garázskaput, hogy beengedje a kertészt, a képkompozíció és a rezignált színészi játék jóformán semmilyen érzelmi változásról nem tudósítanak. Ugyanakkor a kapu nyílásakor a nyugodt csend és a zaklatott zajok olyan valószerútlenül éles kontrasztja észlelhetô, hogy zsigeri módon válik érzékelhetôvé, amint a férfiaktól rettegô Faustában a kertész láttán megnövekszik a feszültség és a fenyegetettségérzet. A generációkon átívelő traumákat hordozó kecsua lány ráadásul a környezetével is a hangokon keresztül, konkrétan énekszóban képes leginkább kapcsolatba kerülni. Ebben a megoldásban olyan andoki indián kulturális hagyományok köszönnek vissza, melyekben a gyász és a traumafeldolgozás az éneklésen keresztül megy végbe (Bloch-Robin 2011; D’Argenio 2013). A huayno tipikusan andoki múfajában alkotó énekesekkel szemben hagyományosan elvárás, hogy egy olyan autentikus zenész-perszónát alkossanak meg, amelyet a valóságban átélt szenvedés hitelesít (Butterworth 2014). Még a modernizált huaynóban is kitüntetett szerep jut ennek a traumafeldolgozó funkciónak. Ahogy James Butterworth etnomuzikológus egyik perui interjúalanya fogalmaz: „vannak lányok, akik azért énekelnek, mert nem tudják elmondani. A szenvedés miatt tanulnak meg énekelni." (Butterworth 2014: 223) Fausta a filmben anyjától az éneklésen keresztül történő kommunikáció kulturális gyakorlatát és az üldöztetés, illetve a nemi erôszak traumája által okozott rettegést kapta örökül. A szereplốt alakító 
Magaly Solier a Fényes ösvény elleni harcok egyik központi helyszínéról, Ayacuchóból származik, és éppen a Fausta énekével egyidôben jelentette meg elsố szólólemezét, Warmi (Nô) címmel, melyben modernizált andoki huaynókat énekel. Saját maga által írt dalszövegei a perui vidéken éló indián nôk ellen elkövetett erôszakról szólnak (cancioneros.com 2009), vagyis a múvészi perszóna és az azt hitelesítô valós élettörténet nála is hangsúlyosan összecsúszik.

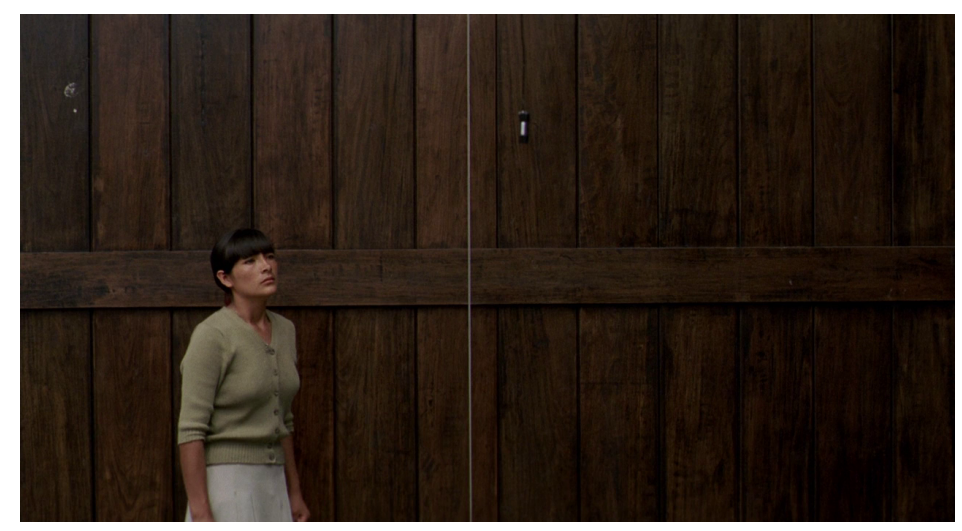

Fausta éneke (La teta asustada. Claudia Llosa, 2009)

Az összeegyeztethetetlen világértelmezések találkozását tehát a Fausta éneke esetében a filmes kifejezés érzékszervi elrendezésének sajátosságai is leképezik, amit a fenomenológia és a „border thinking" logikája segít megérteni. Az érzékszervi és ismeretelméleti viszonyok egyazon jeleneten belül történô megragadásával válik hangsúlyossá, hogy végsố soron nem egyszerúen egymástól elkülönülő emlékezeti diskurzusok versengésérôl van szó, hanem arról, hogy a filmben megjelenô modern és nem modern nézôpontok egyazon valóságon osztoznak, és közvetlen kölcsönhatásban vannak. Ez pedig Llosa múvészetével kapcsolatos általános tanulságokkal is szolgál. A perui születésû́ rendezônő filmjeit ugyanis gyakran titulálják „neo-orientalista vízióknak, melyek pontosan azokat a történeteket mutatják meg a kozmopolita közönségnek, amelyekre az vágyik" (Barrow 2013: 213, kiemelés tôlem). Ezen vizuális diskurzus elnagyolt egzotikumát ugyanakkor a hangsávban megnyilvánuló érzékenység, a nem modern közegből érkezô hősökkel kiépülô érzékszervi közösség ellenpontozza. Llosa munkái így egyensúlyoznak - hol több, hol kevesebb sikerrel - a „modernitás terének túlnyomórészt vizuális logikája” (Shohat és Stam 2014: 214) és a nem modern motívumok testi érzékelésen keresztül történő filmes kifejezése között. 


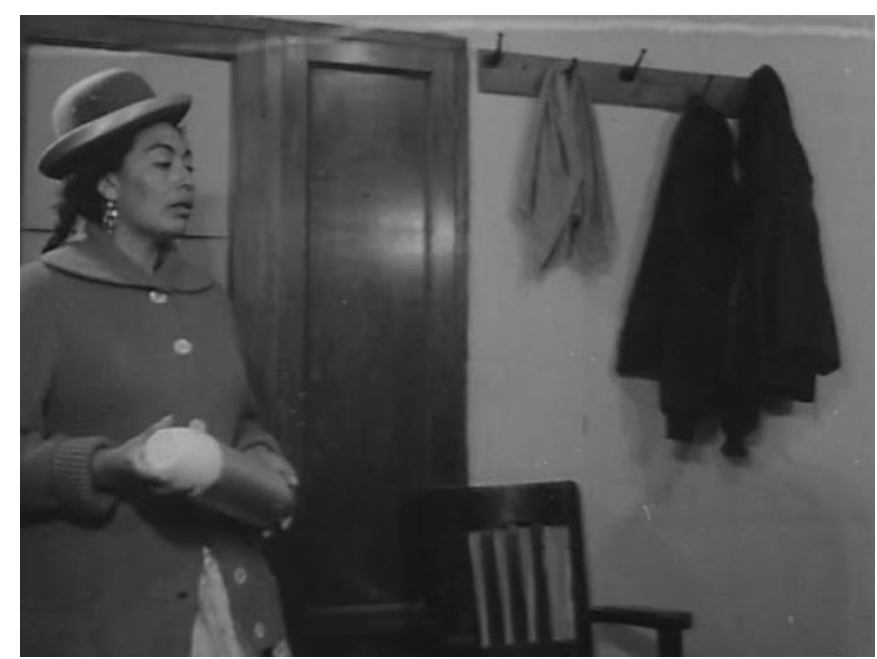

Ukamau (Jorge Sanjinés, 1966)

A fenti stratégia persze csak egy a lehetséges útvonalak közül, amelyeken a filmfenomenológia és a dekoloniális gondolkodás érintkezéséból inspirálódó elemzések elindulhatnak. A filmi szimbólumok és diskurzív jelentésrétegek a filmnézés testet öltött tapasztalatának számos más rétegével kerülhetnek izgalmas kölcsönhatásba (például a tér- és idóérzékelés vagy a haptikusság szenzoriális hatásaival). Az ebben a dolgozatban felvázolt elméleti megfontolások éppen arra hívják fel a figyelmet, hogy a testet öltött észlelés és kifejezés értelmezése a filmek vonatkozásában is megkívánja a konkrét geopolitikai pozíciók, illetve „testbe íródott” élmények differenciált vizsgálatát. Mivel a dekoloniális gondolkodás a latin-amerikai régió kontextusaihoz és gondolati tradícióihoz illeszkedik, és az ezredforduló globalizációjának kritikájából indul ki, ezért e dolgozat számára is a kortárs transznacionális latin-amerikai filmkultúra vizsgálata jelentette az elsôdleges inspirációt. Ugyanakkor például Freya Schiwy ugyancsak Mignolo gondolatmenetéból kiindulva nevezi „border cinemának” a bolíviai Jorge Sanjinés és az Ukamau filmcsoport 70-es és 80-as évekbeli alkotásait, melyek az andoki indiánok világnézetének egyes elemeit és a modern aktivista filmes hagyományok hatásait egyaránt magukon viselik (Schiwy 2009: 73-77.). Tehát további vizsgálatok szükségesek annak megállapítására, hogy az itt felvázolt filmértelmezési keret milyen további korszakokban, illetve geopolitikai kontextusokban alkalmazható, illetve hogy más filmes korpusz elemzésekor is termékenyítóleg hat-e. Indokoltnak tünik ugyanis a modernitás és kolonialitás további találkozási, illetve töréspontjainak filmes kifejezéseit is a helyhez/testhez kötött perspektívák pluralitását figyelembe véve megközelíteni.

\section{Jegyzetek}

1. A talán legtöbbet idézett kivétel Laura U. Marks könyve, a The Skin of the Film: Intercultural Cinema, Embodiment, and the Senses (2000), amely a „haptikus” és az „optikai” látás kettôsségét elemzi az általa „interkulturális mozinak” nevezett korpuszon, vagyis nyugati metropoliszok diaszpóráiban élô, illetve emigráns múvészek kísérleti film- és videómunkáiban. Bár Marks elemzéseinek kiindulópontja a különféle ismeretelméleti paradigmák találkozásának gondolata a vizsgált alkotók és a befogadók vonatkozásában is, érdekes módon a rá hivatkozó, a haptikus vizualitással foglalkozó késôbbi tanulmányok ritkán veszik figyelembe ezt a tényezôt, Marks eredményeit ezzel is az „univerzális tudás” terepére terelve a testet öltött kontextusok specifikumai felól. 
2. A szöveg minden idegen nyelvú idézetét saját fordításban közlöm.

3. Mint Sobchack kifejti, az egzisztenciális fenomenológia aszerint fogalmazza újra Descartes felvetését, „hogy számításba veszi a jelenlétet, a szubjektivitást és az integritást mint egy partikuláris (és mindig társas értelemben vett) testet öltöttség "világban létezését«" (Sobchack 1992: 304).

4. A filmelméleti testi fordulat három trendindító tételeként Jonathan Crary A megfigyelö módszerei (1990), Vivian Sobchack The Address of the Eye (1992) és Steven Shaviro The Cinematic Body (1993) címú munkáját szokás emlegetni.

5. Az „élményekben megragadható test” és a „test mint anatómiai struktúra” szembeállítása ugyanakkor a filmelméleti „testi fordulatot” követően is érezteti hatását, és az egyes irányzatok módszertani eltéréseiben továbbra is tetten érhetô. Míg a fenomenológia jelen szövegben bemutatott elgondolása szerint film és nézố interszubjektív viszonyban áll egymással, a kognitivizmus módszere továbbra is fenntartja a nézôi szubjektum és a nézett objektum elméleti elválasztását, csak a vizsgálati terepébe integrálja az érzékszervek és az idegpályák struktúráit is.

6. A fenomenológia és a filmtudomány összekapcsolásának másik kísérlete Allan Casebier Film and Phenomenology (1991) címú munkája, amely Edmund Husserl transzcendentális fenomenológiájára épül, ellentétben Sobchack filmelméletével, amely Merleau-Ponty egzisztenciális fenomenológiáját veszi alapul. A két megközelítés közötti fố különbség az, hogy míg a transzcendentális fenomenológia szerint az észlelés tárgyai az észlelés aktusától függetlenül léteznek, ezért a szubjektív vagy konstruktív mozzanatot nem építi be a tapasztalat elemzésébe, addig az egzisztenciális fenomenológia a szubjektumot aktív résztvevônek tekinti a tapasztalat konstrukciójában (Antunes 2016: 33-34.).

7. Ezt a mondatot Mignolo javasolja mint a „gondolkodom, tehát vagyok” érvére adott dekoloniális választ, mert szerinte a dekoloniális gondolkodás azáltal tud legitimálni alternatív (tehát nem eurocentrikus) ismeretelméleti opciókat, hogy „kontextusba helyezi Descartes állítását”, vagyis rámutat, hogy az mégsem univerzális, hanem bizonyos geopolitikai és testet öltött pozíciókhoz kötôdik (Mignolo 2011: 91).

8. A dekoloniális gondolkodás értelmezésében „nincs modernitás gyarmatosítás nélkül, a gyarmatosítás a modernitás konstitutív eleme” (Mignolo 2007b: 162). Ezért használják az irányzat szerzôi a „modernitás/kolonialitás” kifejezést és írásmódot: az 500 éve fennálló világrendszer mindkét oldalát figyelembe vevô történeti magyarázatot sürgetnek, ami az eurocentrikus modernitás kapcsán nem csak a bizonyos társadalmi csoportokat érintő felszabadulást, demokratizálódást és fejlôdést veszi számításba, hanem a kolonialitást, vagyis a modernitás „sötét oldalát” is, amelyet a rabszolgatartás, a népirtások, illetve a gazdagság és a földek erôszakos kisajátítása jellemez (Mignolo 2007a: 463-484.).

9. Fáber Ágoston, illetve Lugosi Győző az Eszmélet folyóirat 122. számában (2019. nyár) Quijano „colonitality of power”, illetve „colonialidad del poder” fogalmát a „hatalom gyarmatiságaként” fordítják. Én ugyanakkor ebben a szövegben azért ragaszkodnék a „kolonialitás” kifejezéshez, mert véleményem szerint - ahogy a spanyol „modernidad/colonialidad” vagy az angol „modernity/coloniality” ellentétpár esetében - magyarul is jobban tükrözi a dekoloniális gondolkodás törekvését arra, hogy megragadja a világrendszeren belül a domináns és az alávetett nézőpont közötti komplementer jellegú összetartozást, ha két hasonló csengésú szót helyezünk egymás mellé.

10. Grosfoguel arra hívja fel a figyelmet, hogy a „cogito, ergo sum” karteziánus pillanatát a mintegy 150 évvel korábbi „ego conquistus”, vagyis a hódítás és a gyarmatosítás európai tapasztalata alapozta meg: „a Birodalmi Ego biztosította az ahhoz szükséges arroganciát, hogy az európai szubjektum Istenhez hasonlatossá váljon és valamennyi igaz tudás megalapozójának nyilvánítsa magát. Ez az a fajta szubjektivitás, ami a világ középpontjának érzi magát, mert már meghódította a világot” (Grosfoguel 2007: 215). 
11. Ezzel ellentétben a transzcendentális fenomenológia a testet öltött világon „túl” vagy „afölött” létező tudatból következô univerzális fókuszt választ vizsgálódásainak. Éppen erre a mozzanatra alapozza Mignolo dekoloniális kritikáját, amikor Husserl fenomenológiáját a modernitás/kolonialitás ismeretelméleti viszonyainak újratermelésével vádolja. Lásd: Mignolo, Walter D. (2018): Decoloniality and Phenomenology: The Geopolitics of Knowing and Epistemic/Ontological Colonial Differences. The Journal of Speculative Philosophy, 32.3. 360-387.

12. Llosa életmúvérôl lásd: Margitházi Beja-Máté Bori (2020): Trauma és mágia. In Árva Márton (szerk.): Kino Latino - Latin-amerikai filmrendezőportrék. Budapest, Tudással a Jövőért Közhasznú Alapítvány, 153-170.

\section{Irodalomjegyzék}

- Antunes, Luis Rocha (2016): The Multisensory Film Experience: A Cognitive Model of Experiential Film Aesthetics. Bristol, Intellect.

- Barker, Jennifer M. (2009): The Tactile Eye: Touch and the Cinematic Experience. Berkeley, University of California Press.

- Barrow, Sarah (2013): New Configurations for Peruvian Cinema: The Rising Star of Claudia Llosa. Transnational Cinemas, 4.2. 197-215.

https://doi.org/10.1386/trac.4.2.197_1

- Bloch-Robin, Marianne (2011): De Madeinusa a La teta asustada de Claudia Llosa: la música en la visión del mundo de un autor. El ojo que piensa. Revista de cine iberoamericano, 3. 2021. 10. 02. URL: http://www.elojoquepiensa.cucsh.udg.mx/index.php/elojoquepiensa/article/view/38

- Butterworth, James (2014): The Ethics of Success: Paradoxes of the Suffering Neoliberal Self in the Andean Peruvian Music Industry. Culture, Theory and Critique, 55.2. 212-232. https://doi.org/10.1080/14735784.2014.897243

- Bordwell, David (1985): Narration in the Fiction Film. Madison, University of Wisconsin Press.

- cancioneros.com (2009): La Actriz Protagonista de La Teta Asustada Presentó Su Disco Cantado En Quechua. Cancioneros.Com - Diaria Digital de Música de Autor. 2021. 10. 02. URL: https://www.cancioneros.com/co/364/2/la-actriz-protagonista-de-la-teta-asustada-presentosu-disco-cantado-en-quechua-.

- Dussel, Enrique (1998): Beyond Eurocentrism: The World-System and the Limits of Modernity. In The Cultures of Globalization. Szerk. Fredric Jameson és Masao Miyoshi. Durham-London, Duke University Press. 3-31. https://doi.org/10.2307/j.ctv1lcw3dt.5

- Halle, Randall (2010): Offering Tales They Want to Hear: Transnational European Film Funding as Neo-Orientalism. In Global Art Cinema - New Theories and Histories. Szerk. Karl Schoonover és Rosalind Galt. New York, Oxford University Press. 303-319.

- Elsaesser, Thomas és Malte Hagener (2009): Film Theory: An Introduction Through the Senses. New York, Routledge. https://doi.org/10.4324/9780203876879

- Escobar, Arturo (2007): Worlds and Knowledges Otherwise: The Latin American Modernity/Coloniality Research Program. Cultural Studies, 21.2-3. 179-210. https://doi.org/10.1080/09502380601162506

- Grosfoguel, Ramón (2002): Colonial Difference, Geopolitics of Knowledge, and Global 
Coloniality in the Modern/Colonial Capitalist World-System. Review, 25.3. 203-224.

https://doi.org/10.1080/09502380601162514

- Grosfoguel, Ramón (2007): The Epistemic Decolonial Turn: Beyond Political-Economy Paradigms. Cultural Studies, 21.2-3. 211-223.

- Marks, Laura U. (2000): The Skin of the Film: Intercultural Cinema, Embodiment, and the Senses. Durham-London, Duke University Press. https://doi.org/10.2307/j.ctv1198x4c

- Marks, Laura U. (2008): Thinking Multisensory Culture. Paragraph, 31.2. 123-137. https://doi.org/10.3366/E0264833408000151

- Mignolo, Walter D. (2007a): Delinking: The Rhetoric of Modernity, the Logic of Coloniality and the Grammar of de-Coloniality. Cultural Studies, 21.2-3. 449-514.

https://doi.org/10.1080/09502380601162647

- Mignolo, Walter D. (2007b): Introduction: Coloniality of Power and de-Colonial Thinking. Cultural Studies, 21.2-3. 155-167. https://doi.org/10.1080/09502380601162498

- Mignolo, Walter D. (2011): The Darker Side of Western Modernity: Global Futures, Decolonial Options . Durham-London, Duke University Press. https://doi.org/10.1215/9780822394501

- Mignolo, Walter D. (2012): Local Histories/Global Designs: Coloniality, Subaltern Knowledges, and Border Thinking. [2000] Princeton, Princeton University Press. https://doi.org/10.23943/princeton/9780691156095.001.0001

- Plantinga, Carl (2009): Moving Viewers: American Film and the Spectator's Experience. Berkeley-Los Angeles, University of California Press. https://doi.org/10.1525/9780520943919

- Quijano, Aníbal (2000): Coloniality of Power, Eurocentrism, and Latin America. Nepantla: Views from South, 1.3. 533-580. https://doi.org/10.1177/0268580900015002005

- Quijano, Aníbal (2007): Coloniality and Modernity/Rationality. Cultural Studies, 21.2-3. $168-178$. https://doi.org/10.1080/09502380601164353

- Rutherford, Anne (2006): What Makes a Film Tick? Cinematic Affect, Materiality and Mimetic Innervation. Bern, Peter Lang.

- Schiwy, Freya (2009): Indianizing Film: Decolonization, the Andes, and the Question of Technology. New Brunswick -New Jersey-London, Rutgers University Press.

- Schroeder Rodríguez, Paul A. (2016): Latin American Cinema: A Comparative History. Oakland, University of California Press. https://doi.org/10.1525/9780520963535

- Shaviro, Steven (1993): The Cinematic Body. Minneapolis, University of Minnesota Press.

- Shohat, Ella és Robert Stam (2014): Unthinking Eurocentrism: Multiculturalism and the Media. [1994] New York, Routledge. https://doi.org/10.4324/9781315771441

- Sobchack, Vivian (1992): The Address of the Eye: A Phenomenology of Film Experience. Princeton, Princeton University Press. https://doi.org/10.1515/9780691213279 
- Sobchack, Vivian (2004): Carnal Thoughts: Embodiment and Moving Image Culture. Berkeley-Los Angeles-London, University of California Press.

https://doi.org/10.1525/9780520937826

\section{Filmográfia}

- Fausta éneke (La teta asustada. Claudia Llosa, 2009) 
(C) Apertúra, 2021. tél | www.apertura.hu

webcím: https://www.apertura.hu/2021/tel/arva-perspektivavaltasok-a-filmfenomenologia-es-a-

dekolonialis-gondolkodas-lehetseges-parbeszederol/

https://doi.org/10.31176/apertura.2021.16.2.10

(Q) opertúro 